\title{
Resistance of the stable fly, Stomoxys calcitrans (Diptera: Muscidae), to cypermethrin in outbreak areas in Midwestern Brazil
}

\author{
Resistência da mosca-dos-estábulos, Stomoxys calcitrans (Diptera: Muscidae), à cipermetrina em \\ áreas de surtos no Centro-Oeste brasileiro
}

Antonio Thadeu Medeiros de Barros* (1); Vinícius Duarte Rodrigues²; Paulo Henrique Duarte Cançado; Luísa Nogueira Domingues ${ }^{3}$

\author{
${ }^{1}$ Embrapa Gado de Corte, Campo Grande, MS, Brasil \\ ${ }^{2}$ Curso de Medicina Veterinária, Universidade Católica Dom Bosco - UCDB, Campo Grande, MS, Brasil \\ ${ }^{3}$ USDA-ARS Knipling-Bushland U.S. Livestock Insect Research Laboratory, Kerrville, TX, USA
}

Received May 28, 2019

Accepted September 30, 2019

\begin{abstract}
Population explosions of the stable fly (Stomoxys calcitrans) have become a serious concern for livestock producers near sugarcane mills in some regions of Brazil due to the insect's massive reproduction on sugarcane byproducts and waste. Despite the limited efficiency of insecticides for controlling stable fly outbreaks, producers still rely on chemical control to mitigate the alarming infestations in affected areas. This study evaluated the susceptibility of $S$. calcitrans populations to cypermethrin in the state of Mato Grosso do Sul, Brazil. Stable flies were tested from three field populations and two colonies, established from flies previously collected at sugarcane mills. Wild flies were collected with Nzi traps in areas of sugarcane plantations. Both wild and colonized flies were exposed to eleven concentrations of cypermethrin in impregnated filter paper bioassays. All the populations proved to be resistant to cypermethrin, with resistance factors among field populations ranging from 6.8 to 38.6. The intensive use of insecticides has led to the development of pyrethroid resistance in stable fly populations in the proximities of sugarcane mills in the state of Mato Grosso do Sul.
\end{abstract}

Keywords: Chemical control, insecticide resistance, stable fly outbreaks.

\section{Resumo}

Explosōes populacionais da mosca-dos-estábulos (Stomoxys calcitrans) tornaram-se uma séria preocupação para a pecuária próxima a usinas de cana-de-açúcar em algumas regióes do Brasil, devido à massiva reprodução da mosca em resíduos e subprodutos do processamento da cana. Apesar da limitada eficiência dos inseticidas no controle dos surtos desta mosca, produtores dependem do controle químico para mitigar as alarmantes infestaçôes nas áreas afetadas. Este estudo objetivou avaliar a suscetibilidade de populaçóes de S. calcitrans a piretroides no estado de Mato Grosso do Sul, Brasil. Moscas-dos-estábulos de três populaçôes de campo e duas colônias, estabelecidas a partir de moscas previamente coletadas em usinas de cana-de-açúcar, foram testadas. Moscas selvagens foram coletadas com armadilhas Nzi em áreas de cana. Moscas coletadas foram expostas a onze concentraçóes de cipermetrina em bioensaios com papel de filtro impregnado. Todas as populaçóes testadas mostraram-se resistentes ao piretroide, com fatores de resistência variando de 6,8 a 38,6 nas populaçôes de campo. O uso intensivo de inseticidas tem levado ao desenvolvimento de resistência da mosca-dos-estábulos a piretroides em populaçóes próximas a usinas de cana-de-açúcar no estado do Mato Grosso do Sul.

Palavras-chave: Controle químico, resistência a inseticida, surto de mosca-dos-estábulos.

\section{Introduction}

Over the last decade, outbreaks of the stable fly (Stomoxys calcitrans) resulting from its large-scale proliferation in organic wastes and byproducts from ethanol production at sugarcane mills

*Corresponding author: Antonio Thadeu Medeiros de Barros. Embrapa Gado de Corte, Av. Rádio Maia, 830, Vila Popular, CEP 79106-550, Campo Grande, MS, Brasil. e-mail: thadeu.barros@embrapa.br
(CORRÊA et al., 2013) have become an unprecedented problem, causing significant socioeconomic impacts in several municipalities of southeastern and Midwestern Brazil (DOMINGHETTI et al., 2015). In addition to the economic losses resulting from such outbreaks, this pest has resulted in yearly losses of up to US\$ 335 million in Brazilian livestock (GRISI et al., 2014). 
Commercial insecticide products have been widely employed to reduce the alarming infestations in cattle herds close to sugarcane mills, even though no method of controlling stable flies in cattle raised in extensive livestock farming systems has actually proved to be effective (BROCE, 2006). However, the efficiency of chemical control has been threatened by the limited knowledge about the insecticide effects on both immature and adult $S$. calcitrans in the field, as well as by the paucity of information about the susceptibility of stable fly populations to commercial insecticides.

So far, there are no records of stable fly resistance to insecticides in Brazil and a few reports exist worldwide (CILEK \& GREENE, 1994; PITZER et al., 2010; OLAFSON et al., 2011, 2019; SALEM et al., 2012; TAINCHUM et al., 2018). The purpose of this study was to evaluate the susceptibility of colonized and wild S. calcitrans populations from outbreak areas in the state of Mato Grosso do Sul, Brazil, to the pyrethroid cypermethrin.

\section{Materials and Methods}

In July and August 2016, two colonies and three wild populations of $S$. calcitrans were evaluated to determine their susceptibility to cypermethrin, using the impregnated filter paper method (SHEPPARD \& HINKLE, 1987), as described by Barros et al. (2002).

The two strains (CNPGC-1 and CNPGC-2) were reared at Embrapa Beef Cattle. The CNPGC-1 strain was colonized in mid-2011 from flies collected during an outbreak at a sugarcane mill located in the state of Mato Grosso do Sul (municipality of Maracaju). In 2012, the CNPGC-2 strain was colonized similarly, with flies from a sugarcane mill located in the neighboring state of Mato Grosso (municipality of Alto Taquari), also collected during an outbreak. Field collected flies were sampled at sugarcane mills located in the municipalities of Angélica, Maracaju, and Rio Brilhante in the state of Mato Grosso do Sul. Ultimately, the wild flies used in bioassays came from nearby livestock areas and/or emerged from sugarcane cultivation sites.

Insecticide kits containing impregnated filter papers used in the bioassays were produced by diluting technical grade cypermethrin ( $90.07 \%$ purity, donated by Ouro Fino Saúde Animal) in acetone for analysis (Merck) and subsequent impregnation in filter papers (Whatman\#1). From seven to eleven concentrations of cypermethrin $\left(0.8,1.6,2.4,3.2,4.8,6.4,9.6,12.8,25.6,51.2\right.$, and $\left.102.4 \mu \mathrm{g} / \mathrm{cm}^{2}\right)$ were tested, depending on fly abundance at each sampled site. Control filter papers were impregnated with acetone only. Three replicates of about 20 flies each were used per insecticide concentration. Each impregnated paper was used twice, once on each side, over a period of no more than 15 days. The insecticide kits were stored under refrigeration until each field trip.

Colonized stable flies (3-5 days old, fed) were transferred from breeding cages to an entomological net (placed in front of the cage) and from there to plastic Petri dishes through a $1-\mathrm{cm}$ opening made in the middle of the dish bottom (facing up) using a "manual aspirator", as showed in Figure 1A. This device consisted of a soft rubber bulb from an ordinary turkey baster, whose hard plastic base (the turkey baster pipette was cut above the bulb) was attached to a $25 \mathrm{~mL}$ plastic serological pipette by means of a plastic analytical funnel. The funnel cone was reduced to fit the turkey baster base to which it was glued (Figure 1B). The funnel stem was cut, tapered, and glued into a small piece $(2.5 \mathrm{~cm})$ of a $10 \mathrm{~mL}$ plastic serological pipette to fit the diameter of the $25 \mathrm{~mL}$ plastic serological pipette (about $20 \mathrm{~cm}$ long) with the tip cut to match the hole on the Petri dish. A small piece of voile fabric (about $5 \mathrm{~cm}$ diameter) served to tighten the fit between the funnel tip (covered with the small $10 \mathrm{~mL}$-pipette piece) and the larger $25 \mathrm{~mL}$ pipette, while preventing flies from entering the bulb. The flies in the net entered the device by gravity when gently touched upwards and were released into the dishes by pressing the bulb. This device was originally developed for horn flies (Haematobia irritans) using a $10 \mathrm{~mL}$ pipette and has

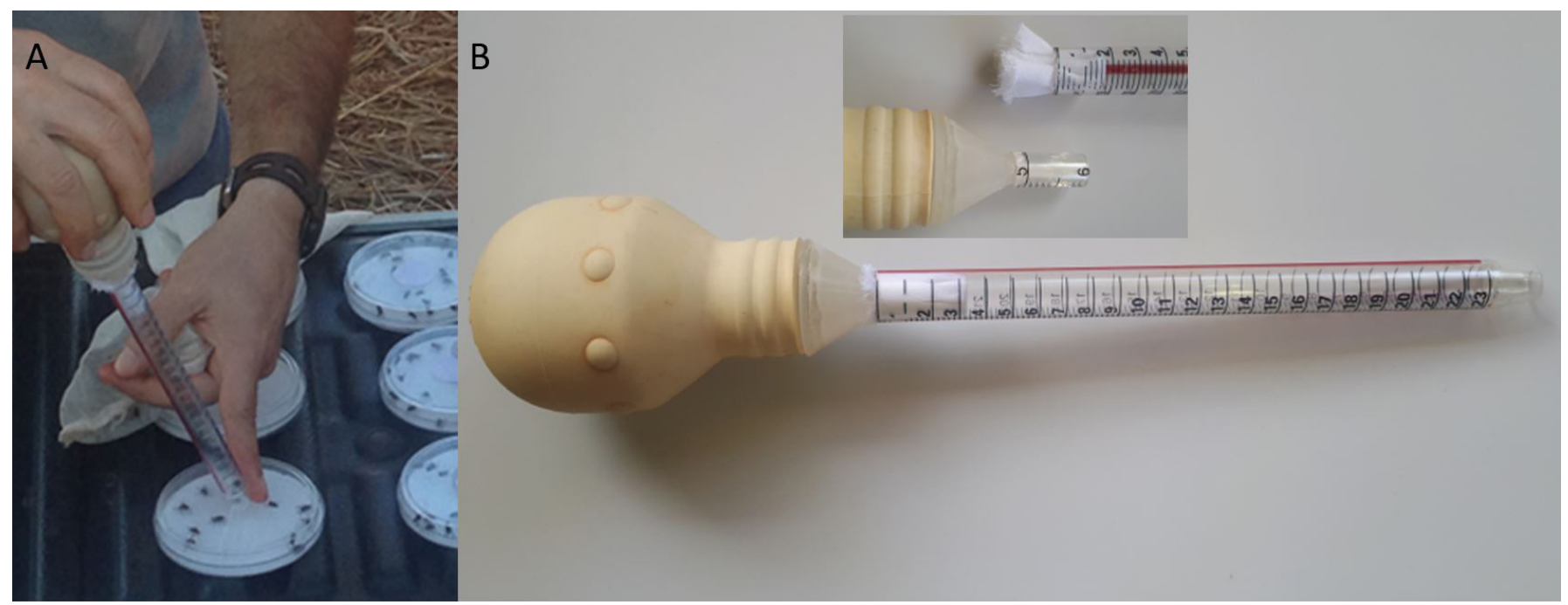

Figure 1. Loading of stable flies into Petri dishes containing insecticide impregnated filter papers (A), using a manual aspirator (B), for susceptibility bioassays. 
been successfully used in bioassays with this pest for more than 20 years (since before BARROS et al., 1999). The adaptation of a larger pipette $(25 \mathrm{~mL})$ for use on stable flies have proved to be equally practical and harmless, making this device a useful tool also for this species.

Wild flies were caught at sugarcane mills using Nzi traps (MIHOK, 2002) (Figure 2A). Ten traps were installed at each site, near cattle areas, dense vegetation and/or vinasse application areas in the morning, and were constantly monitored until a suitable amount of flies (about 700 flies per bioassay) was caught. To prevent heat-related fly mortality, large collectors consisting of transparent plastic jars (3 liters) with screw caps and wide screened sides were used (Figure 2B). If necessary, the flies were removed from collectors as they were caught and kept for a few hours in shady locations until enough flies were collected. To minimize the captivity time of flies, the bioassays conducted at Rio Brilhante and Angélica used ten (0.8-51.2) and seven (1.6-12.8) concentrations, respectively. Trapped flies were transferred to an entomological net and immediately to the dishes containing the impregnated papers, using the manual device described.

Early fly mortality due to collection and/or handling was checked immediately after the dishes were loaded, and dead flies were excluded from the bioassay. Mortality was determined after two hours of exposure to cypermethrin-impregnated filter papers, and flies unable to walk were considered dead. After mortality evaluation, the number of flies (not sexed) was counted on each dish to determine the mortality rate.

Mortality in the treatments was corrected when necessary for mortality in the controls using Abbott's formula (ABBOTT, 1925) and analyzed using POLOPLUS software (LEORA SOFTWARE, 1987) to determine the $\mathrm{LC}_{50}$ (lethal concentration to $50 \%$ of the population) and other related parameters. A bioassay using treated papers from the same batch used in those field and colony bioassays was conducted with stable flies from a susceptible colony at the USDA-ARS Knipling-Bushland U.S. Livestock Insect Research
Laboratory (KBUSLIRL) (Kerrville, TX, USA) to provide a reference of susceptibility. Resistance factors (RF) were calculated by dividing the $\mathrm{LC}_{50}$ of the tested populations by the $\mathrm{LC}_{50}$ of the USDA susceptible strain. Tested populations were considered resistant to cypermethrin when the $95 \%$ fiducial limits (FL) of their $\mathrm{LC}_{50}$ did not overlap the FL of the susceptible strain.

\section{Results and Discussion}

The excessive use of pesticides to control cattle ectoparasites is very common in Brazil, leading to the widespread dissemination of resistance in arthropods such as the southern cattle tick (Rhipicephalus microplus) (KLAFKE et al., 2017) and the horn fly (BARROS et al., 2012). Without infestations that would justify specific control, insecticide resistance in stable flies was probably negligible, but developed over time as a consequence of indirect exposure to chemicals targeting other cattle ectoparasites. However, stable fly selection for resistance has been pushed to an unprecedented level over the last decade by the intensive use of insecticides at both livestock farms and sugarcane mills to prevent and fight stable fly outbreaks.

The three wild stable fly populations evaluated in this study were resistant to cypermethrin, with RFs ranging from 6.8 to 38.6 (Table 1). Resistance of stable flies to insecticide classes has been previously reported for organochlorines, organophosphates and pyrethroids in the U.S. and some European countries (KUNZ \& KEMP, 1994). Pyrethroid resistance in field populations has been confirmed in the U.S. (CILEK \& GREENE, 1994; PITZER et al., 2010) and France (SALEM et al., 2012), and there is evidence of its occurrence elsewhere (EHRHARDT, 2006). To the best of our knowledge, this is the first report of insecticide resistance in stable flies in Latin America. The detection of stable fly resistance revealed a high selection pressure by pyrethroid insecticides at the study sites, which is particularly concerned because Midwestern Brazil is home to the country's largest cattle herd (IBGE, 2016)

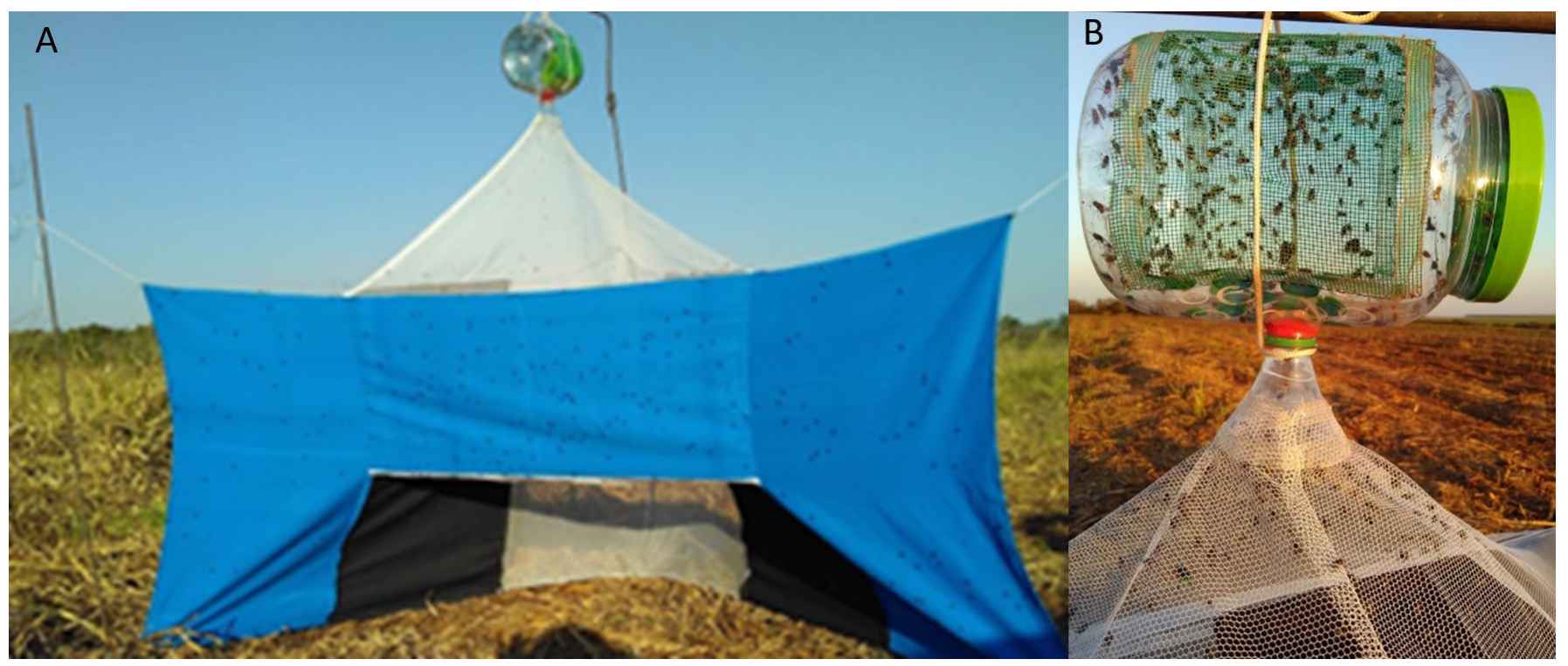

Figure 2. Nzi trap (A) with a large screened collector (B) used for catching Stomoxys calcitrans for field insecticide bioassays. 
Table 1. Cypermethrin dosage-related mortality rates obtained in bioassays with stable fly populations from outbreak areas in the state of Mato Grosso do Sul, Brazil, 2016.

\begin{tabular}{lcccc}
\hline \multicolumn{1}{c}{ Population } & LC $_{\text {50-2h }}$ & $\mathbf{9 5 \% ~ F L}$ & Slope (SE) & RF \\
\hline Colonies* & & & & \\
CNPGC-1 & 18.81 & $15.68-24.46$ & $5.14(0.48)$ & 69.7 \\
CNPGC-2 & 14.48 & $10.68-24.33$ & $3.87(0.33)$ & 53.6 \\
Wild populations & & & & \\
Angélica & 9.85 & $8.80-11.34$ & $3.82(0.60)$ & 36.5 \\
Maracaju & 10.43 & $8.80-12.75$ & $2.77(0.28)$ & 38.6 \\
Rio Brilhante & 1.83 & $0.94-2.63$ & $2.08(0.23)$ & 6.8 \\
Susceptible reference colony & 0.27 & $0.23-0.30$ & $4.66(0.40)$ & - \\
\hline
\end{tabular}

*Stable fly colonies established from adult collections in outbreak areas. $\mathrm{LC}_{50-2 \mathrm{~h}}=$ lethal concentration to $50 \%$ of the population (expressed as $\mu \mathrm{g} / \mathrm{cm}^{2}$ ) after $2 \mathrm{hours}$ exposure to cypermethrin; RF (resistance factor) $=\mathrm{LC}_{50}$ of wild population $/ \mathrm{LC}_{50}$ of the susceptible reference colony $($ Kerrville, USA); FL $=$ Fiducial limits; $\mathrm{SE}=\mathrm{Standard}$ error.

and is its second largest ethanol and sugar producing region (UNICADATA, 2017).

Stable fly resistance to pyrethroids has been first reported for permethrin in a feedlot in Kansas $(\mathrm{RF}=1.8)$ (CILEK \& GREENE, 1994) followed by two field populations in Florida $(\mathrm{RF} \leq 8.9)$ (PITZER et al., 2010). Although stable fly resistance to permethrin has been reported at relatively low levels in the field, a significant increase in resistance levels tends to occur following laboratory selection for a few generations (PITZER et al., 2010). Detection of resistant stable flies in a feedlot with no or minimal insecticide use suggested that dispersal from nearby areas may be a major factor influencing resistance in a population (CILEK \& GREENE, 1994).

The cypermethrin $\mathrm{LC}_{50} \mathrm{~s}$ of the Brazilian stable fly colonies CNPGC-1 and CNPGC-2 were 18.81 and $14.48 \mu \mathrm{g} / \mathrm{cm}^{2}$, respectively, representing 50 -fold higher resistance levels than the susceptible reference colony (Table 1). After more than five years in captivity, such relatively high resistance level found in the two colonies may at first seem somewhat surprising. However, both colonies were established from flies collected during outbreaks, when pyrethroid products were used extensively. In addition, two months prior to this study, the two colonies were almost decimated when they were accidentally exposed to a lambda-cyhalothrin product during a routine insecticide treatment in a nearby laboratory. Thus, the establishment of these colonies from field pyrethroid-exposed flies, later selected by a pyrethroid product, explains their higher level of pyrethroid resistance when compared to that of the wild populations.

There is a paucity of studies on insecticide susceptibility in stable fly populations, partially due to the difficulty in obtaining large numbers of flies for bioassays, since this pest spends little time on hosts, and instead is dispersed in the environment most of the time (FOIL \& HOGSETTE, 1994). In previous susceptibility studies, $S$. calcitrans have been caught using sweep nets on vegetation (CILEK \& GREENE, 1994), vacuuming animal legs (MARÇON et al., 1997), collecting pupae to obtain adults (PITZER et al., 2010) or using Vavoua traps (EHRHARDT, 2006; SALEM et al., 2012). In this study, several major factors may have contributed to the successful capture of adequate numbers of stable flies: their high abundance in sugarcane mill areas, the suitability of trapping sites chosen in each location, and the efficiency of Nzi traps, with which hundreds of stable flies were caught in just a few hours, as previously reported by Mihok (2002) and Gilles et al. (2007).

Mortality in the control groups did not occur in the bioassays with colony flies and was lower than 3\% in bioassays with wild flies. With no exception, a consistent gradient in mortality rates was observed at the cypermethrin concentrations employed in all the colony and field bioassays performed in this study. In contrast to the high variability found by Marçon et al. (1997), who used a different criterion for mortality (flies unable to stand upright), the consistency of the results in the cypermethrin bioassays suggests that the impregnated filter paper bioassay is a suitable method for assessing the susceptibility of stable flies to pyrethroid insecticides.

The detection of resistance in outbreak areas is of great concern because it limits the efficacy of insecticide treatments and contributes to increase the frequency of insecticide applications, particularly when the massive production of flies exceeds their elimination rate, as during fly outbreaks. While efficient non-chemical alternatives are not commercially available, producers at beef cattle ranches, dairy farms and sugarcane mills still rely on chemical control for reducing adult stable fly populations in outbreak areas, despite its limitations. Further studies should bring additional information on the actual extent of stable fly resistance to insecticides in other regions of Brazil subject to outbreaks, and on devising better strategies for controlling this livestock pest.

\section{Acknowledgements}

To the sugarcane mills for allowing the collection of flies and providing logistic support. To BIOSUL (Association of Bioenergy Producers of Mato Grosso do Sul) for assisting visits to the sugarcane mills. To Altair Deitos Jr for his assistance in field activities. To Ouro Fino Saúde Animal for donating cypermethrin. To the USDA-ARS Knipling-Bushland U.S. Livestock Insect Research Laboratory for bioassays with the susceptible colony. And last but not least, to FUNDECT (Mato Grosso do Sul State Foundation for the Support and Development of Education, Science and Technology) and EMBRAPA (Brazilian Agricultural Research Corporation) for the financial support of this work. 


\section{References}

Abbott WS. A method of computing the effectiveness of an insecticide. J Econ Entomol 1925; 18(2): 265-267. http://dx.doi.org/10.1093/ jee/18.2.265a.

Barros ATM, Alison MW Jr, Foil LD. Evaluation of a yearly insecticidal ear tag rotation for control of pyrethroid-resistant horn flies (Diptera: muscidae). Vet Parasitol 1999; 82(4):317-325. http://dx.doi.org/10.1016/ S0304-4017(99)00024-2. PMid:10384908.

Barros ATM, Gomes A, Ismael APK, Koller WW. Susceptibility to diazinon in populations of the horn fly, Haematobia irritans (Diptera: Muscidae), in Central Brazil. Mem Inst Oswaldo Cruz 2002; 97(6): 905-907. http:// dx.doi.org/10.1590/S0074-02762002000600029. PMid:12386720.

Barros ATM, Saueressig TM, Gomes A, Koller WW, Furlong J, Girão ES, et al. Susceptibility of the horn fly, Haematobia irritans irritans (Diptera: Muscidae), to insecticides in Brazil. Rev Bras Parasitol Vet 2012; 21(2): 125-132. http://dx.doi.org/10.1590/S1984-29612012000200010. PMid:22832752.

Broce AB. Ectoparasite control. Vet Clin North Am Food Anim Pract 2006; 22(2): 463-474. http://dx.doi.org/10.1016/j.cvfa.2006.03.006. PMid:16814028.

Cilek JE, Greene GL. Stable fly (Diptera: Muscidae) insecticide resistance in Kansas cattle feedlots. J Econ Entomol 1994; 87(2): 275-279. http:// dx.doi.org/10.1093/jee/87.2.275.

Corrêa EC, Ribas ACA, Campos J, Barros ATM. Abundância de Stomoxys calcitrans (Diptera: Muscidae) em diferentes subprodutos canavieiros. Pesq Vet Bras 2013; 33(11): 1303-1308. http://dx.doi.org/10.1590/ S0100-736X2013001100003

Dominghetti TF, Barros AT, Soares CO, Cançado PH. Stomoxys calcitrans (Diptera: Muscidae) outbreaks: current situation and future outlook with emphasis on Brazil. Rev Bras Parasitol Vet 2015; 24(4): 387-395. http:// dx.doi.org/10.1590/S1984-29612015079. PMid:26689177.

Ehrhardt N. Etude de l'activité d'une formulation à $50 \%$ de deltaméthrine sur Stomoxys calcitrans à la Réunion: résistance et rémanence [thesis]. Toulouse: Ecole Nationale Veterinaire de Toulouse; 2006.

Foil LD, Hogsette JA. Biology and control of tabanids, stable flies and horn flies. Rev Sci Tech 1994; 13(4): 1125-1158. http://dx.doi.org/10.20506/ rst.13.4.821. PMid:7711307.

Gilles J, David JF, Duvallet G, De La Rocque S, Tillard E. Efficiency of traps for Stomoxys calcitrans and Stomoxys niger niger on Reunion Island. Med Vet Entomol 2007; 21(1): 65-69. http://dx.doi.org/10.1111/j.13652915.2006.00658.x. PMid:17373948.

Grisi L, Leite RC, Martins JRS, Barros ATM, Andreotti R, Cançado PHD, et al. Reassessment of the potential economic impact by cattle parasites in Brazil. Rev Bras Parasitol Vet 2014; 23(2): 150-156. http:// dx.doi.org/10.1590/S1984-29612014042. PMid:25054492.

Instituto Brasileiro de Geografia e Estatística - IBGE. Pesquisa da pecuária municipal [online]. Rio de Janeiro: IBGE; 2016 [cited 2018 July 20]. Available from: https:/www.ibge.gov.br/estatisticas/economicas/agriculturae-pecuaria/9107-producao-da-pecuaria-municipal.html?=\&t=resultados
Klafke G, Webster A, Dall Agnol B, Pradel E, Silva J, De La Canal $\mathrm{LH}$, et al. Multiple resistance to acaricides in field populations of Rhipicephalus microplus from Rio Grande do Sul state, Southern Brazil. Ticks Tick Borne Dis 2017; 8(1): 73-80. http://dx.doi.org/10.1016/j. ttbdis.2016.09.019. PMid:27717758.

Kunz SE, Kemp DH. Insecticides and acaricides: resistance and environmental impact. Rev Sci Tech 1994; 13(4): 1249-1286. http:// dx.doi.org/10.20506/rst.13.4.816. PMid:7711312.

Leora Software. POLO-PC a user's guide to probit or logit analysis. Berkeley: LeOra Software; 1987.

Marçon PCRG, Thomas GD, Siegfried BD, Campbell JB. Susceptibility of stable flies (Diptera: Muscidae) from southeastern Nebraska beef cattle feedlots to selected insecticides and comparison of 3 bioassay techniques. J Econ Entomol 1997; 90(2): 293-298. http://dx.doi.org/10.1093/ jee/90.2.293. PMid:9145029.

Mihok S. The development of a multipurpose trap (the Nzi) for tsetse and other biting flies. Bull Entomol Res 2002; 92(5): 385-403. http:// dx.doi.org/10.1079/BER2002186. PMid:12241564.

Olafson PU, Kaufman PE, Duvallet G, Solórzano JA, Taylor DB, Fryxell RT. Frequency of $k d r$ and $k d r-h i s$ alleles in stable fly (Diptera: Muscidae) populations from the United States, Costa Rica, France and Thailand. $J$ Med Entomol 2019; 56(4): 1145-1149. http://dx.doi.org/10.1093/jme/ tjz012. PMid:30768670.

Olafson PU, Pitzer JB, Kaufman PE. Identification of a mutation associated with permethrin resistance in the para-type sodium channel of the stable fly (Diptera: muscidae). J Econ Entomol 2011; 104(1): 250-257. http:// dx.doi.org/10.1603/EC10307. PMid:21404865.

Pitzer JB, Kaufman PE, Tenbroeck SH. Assessing permethrin resistance in the stable fly (Diptera: Muscidae) in Florida by using laboratory selections and field evaluations. J Econ Entomol 2010; 103(6): 2258-2263. http:// dx.doi.org/10.1603/EC10166. PMid:21309252.

Salem A, Bouhsira E, Liénard E, Melou AB, Jacquiet P, Franc M. Susceptibility of two European strains of Stomoxys calcitrans (L.) to cypermethrin, deltamethrin, fenvalerate, $\lambda$-cyhalothrin, permethrin and phoxim. Int J Appl Res Vet Med 2012; 10(3): 249-257.

Sheppard DC, Hinkle NC. A field procedure using disposable materials to evaluate horn fly insecticide resistance. J Agric Entomol 1987; 4(1): 87-89.

Tainchum K, Shukri S, Duvallet G, Etienne L, Jacquiet P. Phenotypic susceptibility to pyrethroids and organophosphate of wild Stomoxys calcitrans (Diptera: Muscidae) populations in southwestern France. Parasitol Res 2018; 117(12): 4027-4032. http://dx.doi.org/10.1007/ s00436-018-6109-y. PMid:30324257.

UNICADATA. Moagem de cana-de-açúcar e produção de açúcar e etanol: safra 2017/2018 [online]. São Paulo: UNICADATA; 2017 [cited 2018 July 20]. Available from: http://www.unicadata.com.br/historico-deproducao-e-moagem.php?idMn=32\&tipoHistorico $=4 \&$ acao $=$ visualiz ar\&idTabela $=1984 \&$ safra $=2017 \% 2$ F2018\&estado $=$ RS $\% 2 C S C \% 2 \mathrm{C}$ PR\%2CSP\%2CRJ\%2CMG\%2CES\%2CMS\%2CMT\%2CGO\%2C DF\%2CBA \%2CSE \%2CAL\%2CPE\%2CPB \%2CRN\%2CCE\%2CPI $\% 2 \mathrm{CMA} \% 2 \mathrm{CTO} \% 2 \mathrm{CPA} \% 2 \mathrm{CAP} \% 2 \mathrm{CRO} \% 2 \mathrm{CAM} \% 2 \mathrm{CAC} \% 2 \mathrm{CRR}$ 